\title{
Total synthesis of naturally occurring 1-oxygenated carbazole alkaloids - clausine E, clausenapin, indizoline and formal synthesis of clausenaline D
}

\author{
Durga P. Kamat and Santosh G. Tilve* \\ Department of Chemistry, Goa University, Taleigao Plateau, Goa - 403206, India \\ E-mail: stilve@unigoa.ac.in
}

DOI: https://doi.org/10.24820/ark.5550190.p009.836

\begin{abstract}
Total synthesis of indizoline and clausenapin have been accomplished via a facile functional group transformation of the ester functionality at the C-3 carbon of the key ester intermediate derived from clausine $\mathrm{E}$ by employing $o$-Claisen rearrangement and Wittig homologation as the key steps. An improved synthesis of clausine E was achieved using Eaton's reagent for the annulation step. $O$-allylation of clausine E followed by $o$-Claisen rearrangement and acetylation enabled the formal synthesis of clausenaline D.
\end{abstract}

Keywords: $o$-Claisen rearrangement, Wittig reaction, clausenapin, indizoline, carbazole alkaloids

\section{Introduction}

1-Oxygenated carbazole alkaloids exhibit promising biological activities, leading to a remarkable exploitation of myriad synthetic strategies towards their synthesis. ${ }^{1,2}$ Moreover, there are substantial reports in the literature on the isolation of these alkaloids from various plant sources. ${ }^{3-13}$ For example, clausine E (1) (Fig. 1), ${ }^{3,4}$ isolated from the stem bark of Clausena excavata showed inhibition of rabbit platelet aggregation and vasocontraction. ${ }^{4}$ Indizoline (2) was isolated from various parts of Clausena lansium ${ }^{5-10}$ and also from the roots of Clausena indica. ${ }^{11}$ Various constituents of Clausena lansium along with indizoline showed a significant concentration-dependent inhibition of nitrite production in the case of RAW264.7, a mouse macrophage cell line used to model macrophage-mediated inflammatory events in vitro. Further studies showed that indizoline was also effective in causing significant-concentration dependent inhibition of tumor necrosis factor- $\alpha(\mathrm{TNF}-\alpha)$ which mediates the production of many cytokines during inflammation. ${ }^{6}$ It also exhibited antitumor activity against human cancer cell lines. ${ }^{8}$ Clausenapin (3) was isolated from the leaves of Clausena heptaphylla. ${ }^{12}$ Clausenaline $\mathrm{D}^{13}(\mathbf{5})$ 
was isolated from Clausena lansium. Significant efforts have been devoted to the synthesis of carbazole alkaloids, over the past two decades. ${ }^{2}$ We have earlier reported the synthesis of clausine E using Wittig reaction and annulation as the key steps. ${ }^{14}$

Argade and coworkers reported the first total synthesis of clausenaline D starting from Bocprotected 3-formylindole and dimethyl maleate featuring Wittig reaction, selective monoalkylation, oxidative cleavage of terminal alkene and dehydrative intramolecular cyclization as the crucial steps. ${ }^{16}$ Prior to its isolation clausenapin was synthesized as Huang Minlon reduction product of indizoline. ${ }^{11}$ Unsuccessful attempts were made in the past to synthesize indizoline as well as clausenapin. ${ }^{17} \mathrm{We}$ realized that a library of 1-oxygenated carbazole alkaloids could be synthesized via a common intermediate $\mathbf{1 0}$ which could be obtained from clausine E. Continuing our interest in the application of Wittig reaction in the synthesis of naturally occurring carbazole alkaloids, ${ }^{14}$ we now wish to report the synthesis of clausenapin (3) and indizoline (2). An improved synthesis of clausine E (1) and the formal synthesis of clausenaline D were also accomplished.
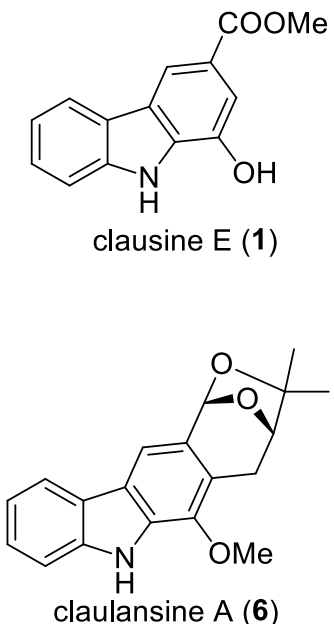
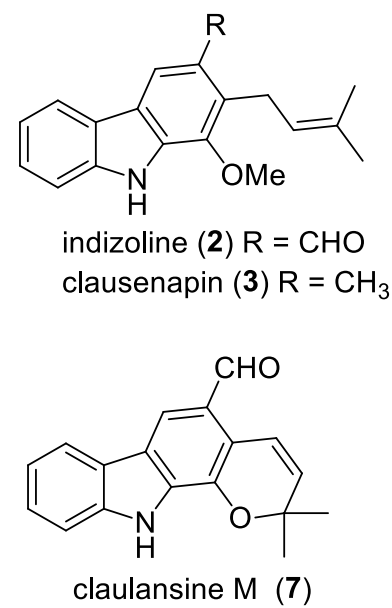
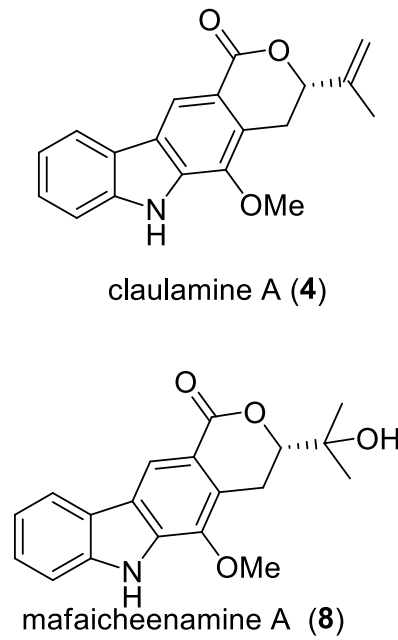

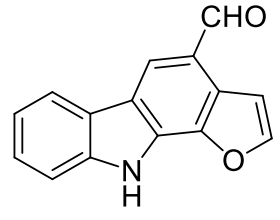

clausenaline D (5)

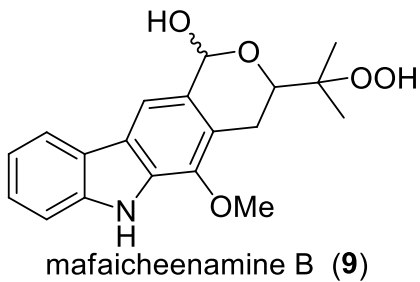

Figure 1. Structures of some naturally occurring 1-oxygenated carbazole alkaloids

We presented our preliminary work on conversion of clausine $\mathrm{E}$ to clausenapin via the intermediate 10, at the NFCFA2015 conference. ${ }^{15}$ Subsequently, in 2016 Humne et al. reported synthesis of clausine E via Fischer-Borsche method and aromatization of 1-oxotetrahydrocarbazole using molecular iodine. ${ }^{18}$ Ullah and coworkers reported the synthesis of intermediate 10 using palladium catalysed $O$-prenylation of clausine E and subsequent microwave assisted $o$ Claisen rearrangement. ${ }^{19}$ Clausine $\mathrm{E}$ was synthesized using palladium acetate catalyzed cyclodehydrogenation of methyl 3-(benzyloxy)-4-(phenylamino) benzoate as the key step. ${ }^{19}$ Intermediate $\mathbf{1 0}$ was utilized for accomplishing the first total synthesis of $( \pm)$-mafaicheenamine A. Chang and coworkers described synthesis of the intermediate 10 using $O$-allylation of 
clausine E and olefin metathesis as the key steps and used it as a precursor for getting indizoline. Further they also synthesized Clausenapin, claulansine $\mathrm{M}$ and clausenaline D from clausine E. ${ }^{20}$ Clausine $\mathrm{E}$ was synthesized by TFAA-mediated annulation of (E)-4-(1'H-indol-3'-yl)-3(methoxycarbonyl)but-3-enoic acid, obtained from Stobbe condensation of indole-3carbaldehyde, ${ }^{21}$ with dimethyl succinate using sodium hydride as a base. ${ }^{20}$ Argade's group accomplished the synthesis of intermediate $\mathbf{1 0}$ by prenylation of the Wittig adduct dimethyl $(E)$ 2-((1-tert-butoxycarbonyl)-1H-indol-3-yl)methylene)succinate followed by selective hydrolysis, triphosgene-induced intramolecular acylation and methylation. The intermediate $\mathbf{1 0}$ was then transformed to indizoline, mafaicheenamine A, claulamine A, claulansine A and claulamine E. ${ }^{22}$

\section{Results and Discussion}

We envisioned a rapid entry into indizoline (2) and clausenapin (3) from the elaboration of a common intermediate $\mathbf{1 0}$ involving transformation of the ester function. A brief synthetic strategy for the synthesis of intermediate $\mathbf{1 0}$ is shown below (Scheme 1). Intermediate 10 would be accessible via Wittig homologation of the aldehyde 11. Intermediate 11 would in turn come from carbazole 12 via methylation of the phenolic hydroxyl group and oxidative cleavage of the terminal double bond. Carbazole 12 would come from $O$-allylation and concomitant $o$-Claisen rearrangement of clausine $\mathrm{E}$. We had earlier reported the synthesis of clausine $\mathrm{E}$ by carrying out annulation of acid 13, either using sodium acetate in acetic anhydride followed by treatment with potassium carbonate in methanol or with PPA. ${ }^{14}$ 

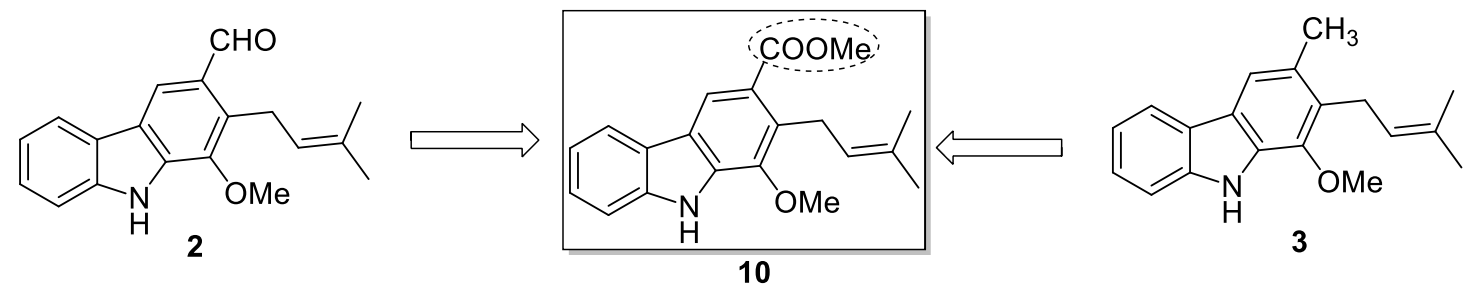<smiles>COc1c(CC=C(C)C)c(C(C)=O)cc2c1[nH]c1ccccc12</smiles>

10<smiles>CCCCOC(=O)c1cc2c([nH]c3ccccc32)c(OC)c1Cc1ccccc1N(CCCC)CCOc1ccccc1</smiles>

11
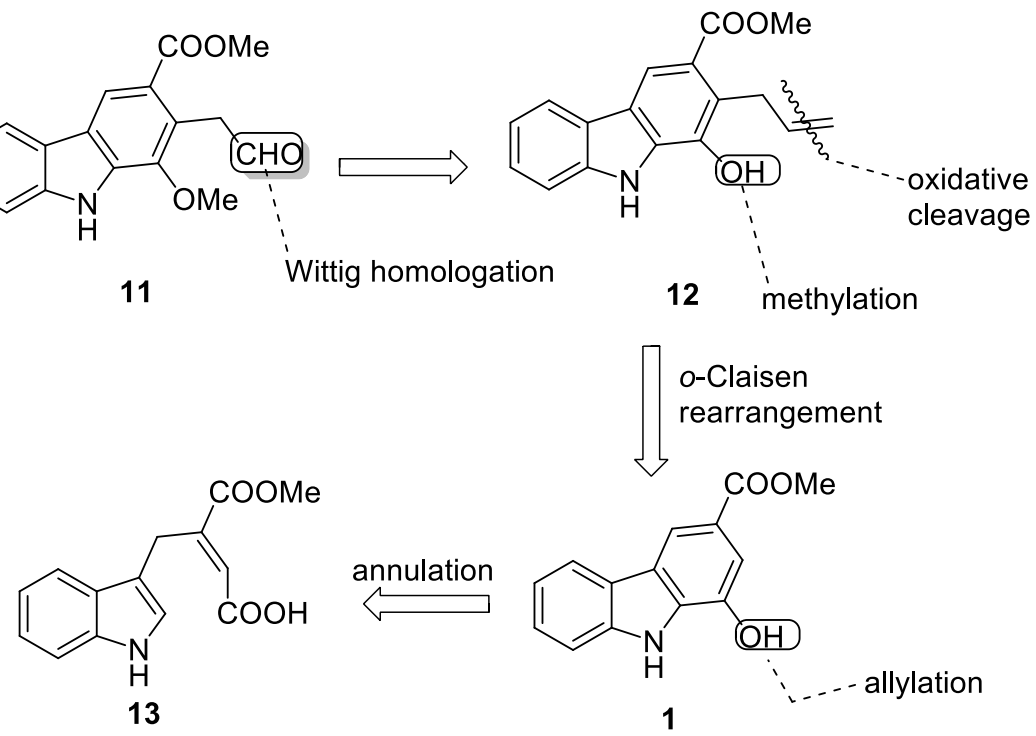

Scheme 1. Retrosynthetic analysis

Our synthetic endeavours started with the acid 13, which was subjected to annulation with the Eaton's reagent to give clausine E (1). ${ }^{23}$ Use of Eaton's reagent helped in decreasing the reaction time, improved the product yield and also allowed for an easy and clean workup procedure. 
<smiles>CC(=O)C(=CC(=O)O)Cc1c[nH]c2ccccc12</smiles>

13<smiles>COc1c(CC=O)c(C(C)=O)cc2c1[nH]c1ccccc12</smiles>
11 vi 10<smiles>C#CC=CC(C)=CCc1c(C=O)cc2c([nH]c3ccccc32)c1OC</smiles>
2

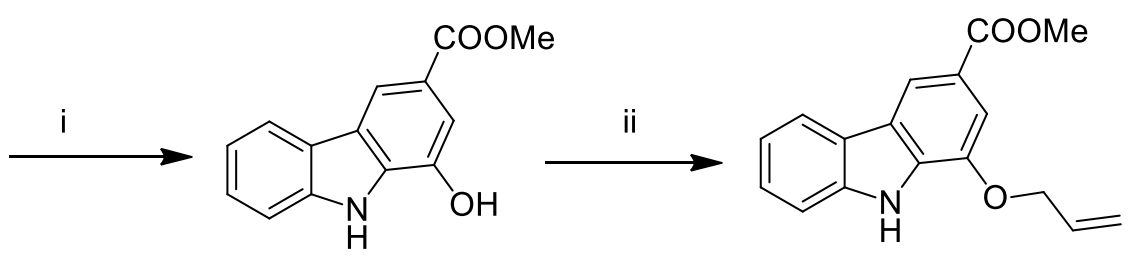

1

14<smiles>[3H]C#C</smiles><smiles>C=CCc1c(C(=O)OC)cc2c([nH]c3ccccc32)c1O</smiles>
15

Reagents and conditions: (i) Eaton's reagent, r.t., $1.5 \mathrm{~h}, 60 \%$; (ii) $\mathrm{K}_{2} \mathrm{CO}_{3}$, acetone, allyl bromide, reflux, 2 h, 71\%; (iii) o-dichlorobenzene, reflux, $45 \mathrm{~min}, 75 \%$; (iv) $\mathrm{K}_{2} \mathrm{CO}_{3}$, acetone, Mel, r.t., 2 h, 89\%; (v) $\mathrm{OsO}_{4}, \mathrm{NaIO}_{4}, \mathrm{THF}: \mathrm{H}_{2} \mathrm{O}(3: 1), 0{ }^{\circ} \mathrm{C}$-r.t., $10 \mathrm{~h}, 70 \%$; (vi) triphenylphosphonium isopropyl iodide, NaHMDS, THF $-10{ }^{\circ} \mathrm{C}$-r.t., 1 h, $70 \%$; (vii) a. LAH, THF r.t., 2 h, b. DMP, DCM, $0{ }^{\circ} \mathrm{C}, 0.5$ h, $78 \%$; (viii) LAH, DCM: $\mathrm{Et}_{2} \mathrm{O}(1: 1)$, r.t., 5 h, $75 \%$.

Scheme 2. Synthesis of clausine E, indizoline and clausenapin.

Clausine $\mathrm{E}$ was then reacted with allyl bromide in acetone using $\mathrm{K}_{2} \mathrm{CO}_{3}$ as base to give 14 in $71 \%$ yield. The Claisen rearrangement of $\mathbf{1 4}$ in refluxing $o$-dichlorobenzene gave $\mathbf{1 2}$ in $75 \%$ yield. The initial attempts of Claisen rearrangement of intermediate $\mathbf{1 4}$ in $N, N$-dimethylaniline resulted in formation of the product in little lower yield (67\%). The chemoselective methylation on the phenolic hydroxyl group of the Claisen rearrangement product $\mathbf{1 2}$ was achieved by using $\mathrm{K}_{2} \mathrm{CO}_{3}$-MeI in acetone. ${ }^{24}$ Compound $\mathbf{1 5}$ was transformed into the desired aliphatic aldehyde $\mathbf{1 1}$ by an in situ oxidative cleavage of the double bond, via the diol using $\mathrm{OsO}_{4}$ and $\mathrm{NaIO}_{4}{ }^{16}$ The carbazole 11 was then treated with triphenyl(propan-2-ylidene)phosphorane, ${ }^{25}$ obtained in situ by 
the reaction of triphenylphosphonium isopropyl iodide with NaHMDS, to produce the desired intermediate 10. The ester function in the intermediate $\mathbf{1 0}$ was successfully transformed into an aldehyde, on treatment with lithium aluminium hydride in THF followed by Dess-Martin periodinane mediated oxidation ${ }^{26}$ resulting in the total synthesis of indizoline (2). The synthesis of clausenapin (3) was achieved from 10, by treatment with excess LAH (Scheme 2).

We also realized that the formal synthesis of clausenaline D (5) could be accomplished through intermediate $\mathbf{1 6} .{ }^{16}$ With carbazole $\mathbf{1 4}$ in hand, we easily synthesized intermediate $\mathbf{1 6}$ by refluxing 14 with sodium acetate in acetic anhydride, involving a one pot $o$-Claisen rearrangement and acetylation sequence (Scheme 3).

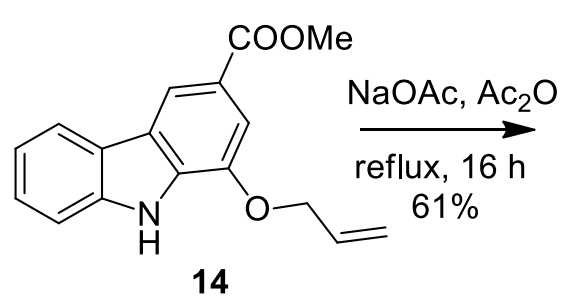

14

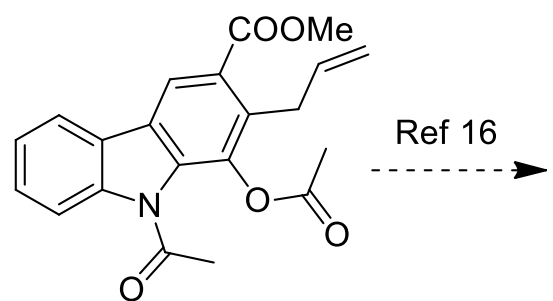

16

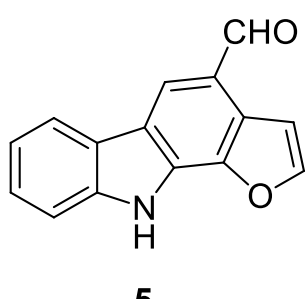

5

Scheme 3. Formal synthesis of clausenaline D.

\section{Conclusions}

In conclusion, we have accomplished the synthesis of prenylated carbazole alkaloids; indizoline, clausenapin, a formal synthesis of clausenaline D, and an improved synthesis of clausine E. Synthesis of intermediate $\mathbf{1 0}$ completes the formal synthesis of claulamine A, claulansine A and mafaicheenamine A. Protection of the indole nitrogen was not vital, which helped in avoiding additional protection-deprotection steps throughout the synthesis.

\section{Experimental Section}

General. Melting points were recorded in open capillary tubes with Thiele's apparatus and are uncorrected. The IR spectra were recorded with a Shimadzu FTIR spectrophotometer. The ${ }^{1} \mathrm{H}$ (400 MHz) and ${ }^{13} \mathrm{C}(100 \mathrm{MHz}) \mathrm{NMR}$ spectra were recorded on a Bruker Avance 400 instrument using $\mathrm{CDCl}_{3}, \mathrm{DMSO}-\mathrm{d}_{6}$ or acetone- $\mathrm{d}_{6}$ as solvent. Chemical shifts $\delta$ are expressed relative to TMS, the coupling constants $J$ are given in Hz. The multiplicities of the carbon signals were obtained from DEPT-135 experiment. HRMS were recorded with a Micro-Mass ES-QTOF. Reactions were monitored by thin layer chromatography with TLC silica gel 60 F254 purchased from Merck. Column chromatography was performed on silica gel (60-120 mesh). Flash chromatography was performed on silica gel (230-400). Commercial reagents were purchased 
from Sigma Aldrich or Spectrochem and used without further purification. The solvents were distilled prior to use.

Methyl 1-hydroxy-9H-carbazole-3-carboxylate (1). Freshly prepared Eaton's reagent (1 : 10 phosphorus pentoxide-methanesulfonic acid solution, $2.5 \mathrm{~mL})^{23}$ was added to $(E)-3-((1 \mathrm{H}-$ indol3-yl)methyl)-4-methoxy-4-oxobut-2-enoic acid (13) (0.8 g, $0.00308 \mathrm{~mol})$ and stirred at ambient temperature for 90 minutes. To the resulting reaction mixture water $(20 \mathrm{~mL})$ was added and extracted with ethyl acetate $(3 \times 30 \mathrm{~mL})$. The combined organic extracts were dried over anhydrous $\mathrm{Na}_{2} \mathrm{SO}_{4}$ and concentrated under reduced pressure. The crude residue was subjected to column chromatographic purification on silica gel using hexane :ethyl acetate $(75: 25)$ as an eluent to give 1 as a white solid. Yield: $0.449 \mathrm{~g}, 60 \%$. The spectral data of 1 matched with the previously reported values. ${ }^{14}$

Methyl 1-(allyloxy)-9H-carbazole-3-carboxylate (14). To a suspension of 1 (0.6 g, 0.00248 $\mathrm{mol})$ in $\mathrm{K}_{2} \mathrm{CO}_{3}(0.68 \mathrm{~g}, 0.00497 \mathrm{~mol})$ and acetone $(15 \mathrm{~mL})$ was added allyl bromide $(0.21 \mathrm{~mL}$, $0.00248 \mathrm{~mol})$ at room temperature under argon atmosphere and the reaction mixture was subjected to reflux for 2 hours. The mixture was filtered, the filtrate was concentrated under vacuum and the remaining residue was purified by flash chromatography on silica gel using hexane : ethyl acetate $(90: 10)$ as an eluent to give 14 as a white solid. Yield: $0.499 \mathrm{~g}, 71 \%$, m.p. 178-180 ${ }^{\circ} \mathrm{C}$; (Lit. ${ }^{20} 179-180{ }^{\circ} \mathrm{C}$ ); IR (KBr): 3369, 1687, 1311, $1217 \mathrm{~cm}^{-1}$; ${ }^{1} \mathrm{H}$ NMR (400 MHz, $\left.\mathrm{CDCl}_{3}\right) \delta: 3.99(\mathrm{~s}, 3 \mathrm{H}), 4.79-4.81(\mathrm{dt}, 2 \mathrm{H}, J 1.2 \mathrm{~Hz}, J \quad 5.6 \mathrm{~Hz}),, 5.37-5.40(\mathrm{dd}, 1 \mathrm{H}, J 1.2 \mathrm{~Hz}, J$ $10.4 \mathrm{~Hz}$ ), 5.50-5.55 (dd, 1H, J 1.6 Hz, J 17.2 Hz), 6.13-6.23 (m, 1H), 7.28-7.32 (m, 1H), 7.45$7.52(\mathrm{~m}, 2 \mathrm{H}), 7.61(\mathrm{~d}, 1 \mathrm{H}, J 1.2 \mathrm{~Hz}), 8.12(\mathrm{~d}, J 8 \mathrm{~Hz}, 1 \mathrm{H}), 8.50(\mathrm{~s}, 1 \mathrm{H}), 8.59$ (br s, $1 \mathrm{H}) ;{ }^{13} \mathrm{C} \mathrm{NMR}$ $\left(100 \mathrm{MHz}, \mathrm{CDCl}_{3}\right)$ \&: $52.07\left(\mathrm{CH}_{3}\right), 69.39\left(\mathrm{CH}_{2}\right), 107.84(\mathrm{CH}), 111.25(\mathrm{CH}), 116.36(\mathrm{CH}), 118.42$ $\left(\mathrm{CH}_{2}\right), 120.29(\mathrm{CH}), 120.76(\mathrm{CH}), 121.82(\mathrm{Cq}), 123.74(\mathrm{Cq}), 123.76(\mathrm{Cq}), 126.40(\mathrm{CH}), 132.84$ $(\mathrm{CH}), 133.06(\mathrm{Cq}), 139.52(\mathrm{Cq}), 143.98(\mathrm{Cq}), 167.95(\mathrm{Cq})$; HRMS: $m / z[\mathrm{M}+\mathrm{Na}]^{+}$calculated for $\mathrm{C}_{17} \mathrm{H}_{15} \mathrm{NO}_{3} \mathrm{Na}: 304.0950$, found: 304.0951 .

Methyl 2-allyl-1-hydroxy-9H-carbazole-3-carboxylate (12). A solution of 14 (0.4 g, 0.00142 mol) in ortho dichlorobenzene $(5 \mathrm{~mL})$ under an argon atmosphere was heated at reflux for 45 minutes. The reaction mixture was purified by flash chromatography on silica gel using hexane : ethyl acetate $(75: 25)$ as an eluent to give 12 as a white solid. Yield: $0.3 \mathrm{~g}, 75 \%$; m.p. 147-149 ${ }^{\circ} \mathrm{C}$; IR (KBr): 3346, 3057, 1658, 1620, 1307, $1280 \mathrm{~cm}^{-1}$; ${ }^{1} \mathrm{H}$ NMR (400 MHz, $\left.\mathrm{CDCl}_{3}\right)$ \&: 3.94 (s, $3 \mathrm{H}), 4.02(\mathrm{~d}, 2 \mathrm{H}, J 5.6 \mathrm{~Hz}), 5.17$ (d, 1H, J 5.2 Hz), 5.21 (s, 1H), 5.59 ( s, 1H), 6.11-6.21 (m, 1H), $7.25(\mathrm{~m}, 1 \mathrm{H}), 7.41-7.46(\mathrm{~m}, 2 \mathrm{H}), 8.05(\mathrm{~d}, 1 \mathrm{H}, J 7.6 \mathrm{~Hz}), 8.37(\mathrm{~s}, 1 \mathrm{H}), 8.44(\mathrm{br} \mathrm{s}, 1 \mathrm{H}) ;{ }^{13} \mathrm{C} \mathrm{NMR}$ $\left(100 \mathrm{MHz}, \mathrm{CDCl}_{3}\right) \delta: 31.74\left(\mathrm{CH}_{2}\right), 52.03\left(\mathrm{CH}_{3}\right), 111.18(\mathrm{CH}), 116.01\left(\mathrm{CH}_{2}\right), 117.26(\mathrm{CH})$, $120.18(\mathrm{CH}), 120.60(\mathrm{CH}), 121.81(\mathrm{Cq}), 122.52(\mathrm{Cq}), 123.69(\mathrm{Cq}), 126.36(\mathrm{CH}), 132.28(2 \times$ $\mathrm{Cq}), 136.93(\mathrm{CH}), 139.79(\mathrm{Cq}), 140.51(\mathrm{Cq}), 168.82(\mathrm{Cq})$; HRMS: $m / z$ [M+Na] ${ }^{+}$calculated for $\mathrm{C}_{17} \mathrm{H}_{15} \mathrm{NO}_{3} \mathrm{Na}: 304.0950$, found: 304.0950 .

Methyl 2-allyl-1-methoxy-9H-carbazole-3-carboxylate (15). To a solution of 12 (0.3 g, $0.00106 \mathrm{~mol})$ in acetone $(10 \mathrm{~mL})$ was added $\mathrm{K}_{2} \mathrm{CO}_{3}(0.339 \mathrm{~g}, 0.00245 \mathrm{~mol})$ and after being stirred for 5 minutes at ambient temperature, iodomethane $(0.47 \mathrm{~mL}, 0.00746 \mathrm{~mol})$ was added and the reaction mixture was further stirred for two hours. Acetone was evaporated under 
reduced pressure. The mixture was dissolved in ethyl acetate $(30 \mathrm{~mL})$, washed with water $(10$ $\mathrm{mL}$ ) and dried over anhydrous $\mathrm{Na}_{2} \mathrm{SO}_{4}$ and concentrated under reduced pressure. The crude residue was subjected to column chromatographic purification on silica gel using hexane : ethyl acetate $(90: 10)$ as an eluent to give 15 as a white solid. Yield: 0.28 g, 89\%, m.p. $115-118{ }^{\circ} \mathrm{C}$ (Lit. ${ }^{20} 112-115{ }^{\circ} \mathrm{C}$ ); IR (KBr): 3346, 1681, 1606, 1346, $1263 \mathrm{~cm}^{-1} ;{ }^{1} \mathrm{H} \mathrm{NMR}\left(400 \mathrm{MHz}, \mathrm{CDCl}_{3}\right)$ $\delta: 3.95(\mathrm{~s}, 3 \mathrm{H}), 3.98(\mathrm{~s}, 3 \mathrm{H}), 4.03-4.06(\mathrm{dt}, 2 \mathrm{H}, J 1.6 \mathrm{~Hz}, J 5.6 \mathrm{~Hz}), 4.95-5.04(\mathrm{~m}, 2 \mathrm{H}), 6.10-6.17$ $(\mathrm{m}, 1 \mathrm{H}), 7.28-7.31(\mathrm{~m}, 1 \mathrm{H}), 7.45-7.52(\mathrm{~m}, 2 \mathrm{H}), 8.09$ (d, 1H, J 7.6 Hz), 8.39 (br s, 1H), 8.54 (s, $1 \mathrm{H}) ;{ }^{13} \mathrm{C}$ NMR $\left(100 \mathrm{MHz}, \mathrm{CDCl}_{3}\right) \delta: 30.68\left(\mathrm{CH}_{2}\right), 51.92\left(\mathrm{CH}_{3}\right), 61.43\left(\mathrm{CH}_{3}\right), 111.13(\mathrm{CH})$, $114.60\left(\mathrm{CH}_{2}\right), 120.29(\mathrm{CH}), 120.39(\mathrm{CH}), 120.58(\mathrm{CH}), 122.37(\mathrm{Cq}), 122.92(\mathrm{Cq}), 123.92(\mathrm{Cq})$, $126.46(\mathrm{CH}), 131.19(\mathrm{Cq}), 135.51(\mathrm{Cq}), 138.26(\mathrm{CH}), 139.83(\mathrm{Cq}), 143.43(\mathrm{Cq}), 168.38(\mathrm{Cq})$; HRMS: $m / z$ [M+Na] ${ }^{+}$calculated for $\mathrm{C}_{18} \mathrm{H}_{17} \mathrm{NO}_{3} \mathrm{Na}: 318.1106$, found: 318.1106 .

Methyl 1-methoxy-2-(2-oxoethyl)-9H-carbazole-3-carboxylate (11). To a suspension of 15 $(0.27 \mathrm{~g}, 0.000914)$ in a mixture of THF $(7.5 \mathrm{~mL})$ and water $(2.5 \mathrm{~mL})$ was added $1 \%$ aqueous $\mathrm{OsO}_{4}$ solution $(1.6 \mathrm{~mL}, 0.000063 \mathrm{~mol})$ at $0-5{ }^{\circ} \mathrm{C}$ and the reaction mixture was stirred. After 10 minutes, $\mathrm{NaIO}_{4},(0.879 \mathrm{~g}, 0.00411 \mathrm{~mol})$ was added to the reaction mixture and stirring was continued for 10 hours at ambient temperature. THF was evaporated under vacuum and water $(15 \mathrm{~mL})$ was added to the residue. The reaction mixture was extracted with ethyl acetate $(3 \times 15$ $\mathrm{mL}$ ) and the combined extract was washed with water, brine and dried over sodium sulfate. The organic layer was concentrated in vacuo and the crude residue was purified by flash chromatography on silica gel using hexane : ethyl acetate $(70: 30)$ as an eluent to give $\mathbf{1 1}$ as a white solid. Yield: 0.19 g, 70\%, m.p. 170-172 ${ }^{\circ} \mathrm{C}$ (Lit. ${ }^{20} 171-174{ }^{\circ} \mathrm{C}$ ); IR (KBr): 3338, 1712, 1703, $1282 \mathrm{~cm}^{-1} ;{ }^{1} \mathrm{H}$ NMR (400 MHz, $\mathrm{CDCl}_{3}$ ) $\delta: 3.80$ (s, 3H), 3.84 (s, 3H), 4.25 (s, 2H), 7.18$7.21(\mathrm{~m}, 1 \mathrm{H}), 7.30-7.37(\mathrm{~m}, 2 \mathrm{H}), 7.90(\mathrm{~d}, 1 \mathrm{H}, J 7.6 \mathrm{~Hz}), 8.33(\mathrm{~d}, 1 \mathrm{H}, J 6 \mathrm{~Hz}), 8.59$ (br s, 1H), $9.87(\mathrm{~s}, 1 \mathrm{H}) ;{ }^{13} \mathrm{C}$ NMR $\left(100 \mathrm{MHz}, \mathrm{CDCl}_{3}\right) \delta: 41.79\left(\mathrm{CH}_{2}\right), 51.96\left(\mathrm{CH}_{3}\right), 61.34\left(\mathrm{CH}_{3}\right), 111.31$ $(\mathrm{CH}), 120.41(\mathrm{CH}), 120.51(\mathrm{CH}), 120.57(\mathrm{CH}), 120.72(\mathrm{Cq}), 123.62(\mathrm{Cq}), 123.70(\mathrm{Cq}), 124.76$ $(\mathrm{Cq}), 126.62(\mathrm{CH}), 135.40(\mathrm{Cq}), 140.03(\mathrm{Cq}), 144.00(\mathrm{Cq}), 167.79(\mathrm{Cq}), 200.44$ (CHO); HRMS: $\mathrm{m} / z[\mathrm{M}+\mathrm{Na}]^{+}$calculated for $\mathrm{C}_{17} \mathrm{H}_{15} \mathrm{NO}_{4} \mathrm{Na}: 320.0899$, found: 320.0899 .

Methyl 1-methoxy-2-(3-methylbut-2-en-1-yl)-9H-carbazole-3-carboxylate (10). A flamedried, 2-necked round bottomed flask under argon atmosphere was charged with triphenylphosphonium isopropyl iodide $(0.58 \mathrm{~g}, 0.00134 \mathrm{~mol})$ and anhydrous THF $(10 \mathrm{~mL})$. The solution was cooled to $-10{ }^{\circ} \mathrm{C}$ and $2 \mathrm{M}$ NaHMDS in THF $(0.67 \mathrm{~mL}, 0.00134 \mathrm{~mol})$ was added drop wise (till the dark red colour persisted). After ten minutes, a solution of compound 11 (0.2 $\mathrm{g}, 0.00067 \mathrm{~mol})$ in THF $(5 \mathrm{~mL})$ was added drop wise at $-10{ }^{\circ} \mathrm{C}$ to the reaction mixture. The reaction mixture was then allowed to gradually warm to room temperature and stirred for about one hour. The reaction mixture was quenched with aqueous saturated $\mathrm{NH}_{4} \mathrm{Cl}$ solution $(10 \mathrm{~mL})$. THF was removed under vacuum and the crude mixture was extracted with diethyl ether $(3 \times 15$ $\mathrm{mL}$ ). The combined organic extract was washed with water, brine and dried over sodium sulfate. The organic layer was concentrated in vacuo and the crude residue was purified by flash chromatography on silica gel using hexane : ethyl acetate $(80: 20)$ as an eluent to give $\mathbf{1 0}$ as a white solid. Yield: 0.152 g, $70 \%$, m.p. $140-142{ }^{\circ} \mathrm{C}$ (Lit. ${ }^{20} 139-142{ }^{\circ} \mathrm{C}$ ); IR (KBr): 3342, 1687 , 
1608, $1261 \mathrm{~cm}^{-1} ;{ }^{1} \mathrm{H}$ NMR (400 MHz, acetone-d 6$) \delta: 1.65$ (s, 3H), $1.81(\mathrm{~s}, 3 \mathrm{H}), 3.88(\mathrm{~s}, 3 \mathrm{H}), 3.93$ $(\mathrm{d}, 2 \mathrm{H}, J 6.4 \mathrm{~Hz}), 3.95$ (s, 3H), 5.22-5.25 (t, 1H, J 6.4 Hz), 7.21-7.25 (t, 1H, J 7.6 Hz), 7.41-7.45 $(\mathrm{t}, 1 \mathrm{H}, J 7.6 \mathrm{~Hz}), 7.56(\mathrm{~d}, 1 \mathrm{H}, J 8.4 \mathrm{~Hz}), 8.15(\mathrm{~d}, 1 \mathrm{H}, J 8 \mathrm{~Hz}), 8.48(\mathrm{~s}, 1 \mathrm{H}), 10.73(\mathrm{br} \mathrm{s}, 1 \mathrm{H}) ;{ }^{13} \mathrm{C}$ NMR (100 MHz, acetone-d 6$) \delta: 18.19\left(\mathrm{CH}_{3}\right), 25.91\left(\mathrm{CH}_{3}\right), 26.33\left(\mathrm{CH}_{2}\right), 52.02\left(\mathrm{CH}_{3}\right), 61.25$ $\left(\mathrm{CH}_{3}\right), 112.34(\mathrm{CH}), 120.37(\mathrm{CH}), 120.64(\mathrm{CH}), 121.10(\mathrm{CH}), 122.95(\mathrm{Cq}), 123.36(\mathrm{Cq}), 124.45$ $(\mathrm{Cq}), 125.49(\mathrm{CH}), 127.05(\mathrm{CH}), 131.14(\mathrm{Cq}), 133.42(\mathrm{Cq}), 136.49(\mathrm{Cq}), 141.58(\mathrm{Cq}), 144.43$ (Cq), $168.96(\mathrm{Cq})$; HRMS: $m / z \cdot[\mathrm{M}+\mathrm{Na}]^{+}$calculated for $\mathrm{C}_{20} \mathrm{H}_{21} \mathrm{NO}_{3} \mathrm{Na}: 346.1419$, found: 346.1419.

Methoxy-3-methyl-2-(3-methylbut-2-en-1-yl)-9H-carbazole (3). To a suspension of LAH $(0.126 \mathrm{~g}, 0.0033 \mathrm{~mol})$ in anhydrous $\mathrm{CH}_{2} \mathrm{Cl}_{2} / \mathrm{Et}_{2} \mathrm{O}(6 \mathrm{~mL}, 1: 1)$ was added drop wise compound 10 (0.09 g, $0.000278 \mathrm{~mol})$ dissolved in anhydrous $\mathrm{CH}_{2} \mathrm{Cl}_{2} / \mathrm{Et}_{2} \mathrm{O}(4 \mathrm{~mL}, 1: 1)$ under an argon atmosphere at ambient temperature and stirring was continued for 5 hours. The reaction mixture was quenched with water $(2 \mathrm{~mL})$ at $0{ }^{\circ} \mathrm{C}$ and filtered. The solvent of the filtrate was removed under vacuum, the resulting residue was dissolved in chloroform $(30 \mathrm{~mL})$ and washed with water $(10 \mathrm{~mL})$. The organic layer was dried over anhydrous sodium sulphate, concentrated under vacuum and the residue was subjected to flash column chromatography on silica gel using hexane : ethyl acetate $(90: 10)$ as an eluent to give 3 as a pale red solid. Yield: $0.058 \mathrm{~g}, 75 \%$, m.p. 83-85 ${ }^{\circ} \mathrm{C}$ (Lit. ${ }^{20} 81-83{ }^{\circ} \mathrm{C}$ ); IR (KBr): 3325, 1612, 1338, $1255 \mathrm{~cm}^{-1}$; ${ }^{1} \mathrm{H}$ NMR (400 MHz, acetone-d6) $\delta: 1.69(\mathrm{~s}, 3 \mathrm{H}), 1.83(\mathrm{~s}, 3 \mathrm{H}), 2.42(\mathrm{~s}, 3 \mathrm{H}), 3.53(\mathrm{~d}, 2 \mathrm{H}, J 6.4 \mathrm{~Hz}), 3.92(\mathrm{~s}, 3 \mathrm{H}), 5.11$ $5.15(\mathrm{t}, 1 \mathrm{H}, J 6.4 \mathrm{~Hz}), 7.11-7.15(\mathrm{t}, 1 \mathrm{H}, J 7.2 \mathrm{~Hz}), 7.31-7.35(\mathrm{t}, 1 \mathrm{H}, J 7.2 \mathrm{~Hz}), 7.49$ (d, $1 \mathrm{H}, J 8.4$ $\mathrm{Hz}), 7.66(\mathrm{~s}, 1 \mathrm{H}), 8.01(\mathrm{~d}, 1 \mathrm{H}, J 8 \mathrm{~Hz}), 10.27(\mathrm{br} \mathrm{s}, 1 \mathrm{H}) ;{ }^{13} \mathrm{C}$ NMR (100 MHz, acetone-d 6 ) $\delta$ : $18.07\left(\mathrm{CH}_{3}\right), 20.15\left(\mathrm{CH}_{3}\right), 25.83\left(\mathrm{CH}_{3}\right), 26.46\left(\mathrm{CH}_{2}\right), 61.09\left(\mathrm{CH}_{3}\right), 111.88(\mathrm{CH}), 117.50(\mathrm{CH})$, $119.52(\mathrm{CH}), 120.64(\mathrm{CH}), 123.94(\mathrm{Cq}), 124.37(\mathrm{Cq}), 124.40(\mathrm{CH}), 125.99(\mathrm{CH}), 129.05(\mathrm{Cq})$, $130.58(\mathrm{Cq}), 131.58(\mathrm{Cq}), 132.70(\mathrm{Cq}), 141.17(\mathrm{Cq}), 144.21(\mathrm{Cq})$. HRMS: m/z [M+H] ${ }^{+}$ calculated for $\mathrm{C}_{19} \mathrm{H}_{22} \mathrm{NO}$ : 280.1701, found: 280.1701 .

1-Methoxy-2-(3-methylbut-2-en-1-yl)-9H-carbazole-3-carbaldehyde (2). To a suspension of LAH $(0.025 \mathrm{~g}, 0.000649 \mathrm{~mol})$ in anhydrous THF $(4 \mathrm{~mL})$ was added drop wise compound 10 $(0.07 \mathrm{~g}, 0.000216 \mathrm{~mol})$ dissolved in THF (4 mL) under an argon atmosphere. The reaction was stirred for 2 hours at ambient temperature. The reaction mixture was quenched with water $(3 \mathrm{~mL})$ at $0{ }^{\circ} \mathrm{C}$ and filtered. The solvent of the filtrate was removed under vacuum. The crude residue was dissolved in dry $\mathrm{CH}_{2} \mathrm{Cl}_{2}(5 \mathrm{~mL})$ and DMP (0.0918 g, $\left.0.000216 \mathrm{~mol}\right)$ was added to it under argon atmosphere at $0{ }^{\circ} \mathrm{C}$. After stirring for 0.5 hours, $\mathrm{CH}_{2} \mathrm{Cl}_{2}$ was evaporated under vacuum and the reaction mixture was diluted with ether $(20 \mathrm{~mL})$ and washed with $10 \% \mathrm{Na}_{2} \mathrm{CO}_{3}$ solution (10 $\mathrm{mL})$ and water $(10 \mathrm{~mL})$. The organic layer was dried over anhydrous sodium sulfate and evaporated under reduced pressure. The crude residue was purified by flash chromatography on silica gel using hexane : ethyl acetate $(80: 20)$ as an eluent to give $\mathbf{2}$ as a white solid. Yield: 0.049 g, 78\%, m.p. $168-170{ }^{\circ} \mathrm{C}$ (Lit. ${ }^{20} 168-171{ }^{\circ} \mathrm{C}$ ); IR (KBr): 3315, 1724, 1666, $1242 \mathrm{~cm}^{-1} ;{ }^{1} \mathrm{H}$ NMR (400 MHz, acetone-d $)_{6} \delta: 1.67(\mathrm{~s}, 3 \mathrm{H}), 1.85$ (s, 3H), 3.98 (s, 3H), 4.00 (d, 2H, J 6.8 Hz), 5.22-5.26 (m, 1H), 7.25-7.29 (m, 1H), 7.44-7.48 (m, 1H), 7.59 (d, 1H, J 8 Hz), 8.21 (d, 1H, J 7.6 $\mathrm{Hz}) 8.47(\mathrm{~s}, 1 \mathrm{H}), 10.26(\mathrm{~s}, 1 \mathrm{H}), 10.93($ br s, $\left.1 \mathrm{H}) ;{ }^{13} \mathrm{C} \mathrm{NMR}(100 \mathrm{MHz} \text {, acetone-d })_{6}\right): \delta 18.18$ 
$\left(\mathrm{CH}_{3}\right), 24.62\left(\mathrm{CH}_{2}\right), 25.82\left(\mathrm{CH}_{3}\right), 61.51\left(\mathrm{CH}_{3}\right), 112.53(\mathrm{CH}), 121.05(\mathrm{CH}), 121.30(\mathrm{CH}), 122.61$ $(\mathrm{CH}), 123.98(\mathrm{Cq}), 124.62(\mathrm{Cq}), 125.24(\mathrm{CH}), 127.33(\mathrm{CH}), 128.54(\mathrm{Cq}), 131.73(\mathrm{Cq}), 133.90$ $(\mathrm{Cq}), 137.77(\mathrm{Cq}), 141.62(\mathrm{Cq}), 144.19(\mathrm{Cq}), 192.06$ (CHO).

Methyl 1-acetoxy-9-acetyl-2-allyl-9H-carbazole-3-carboxylate (16). To a solution of 14 (0.11 $\mathrm{g}, 0.00039 \mathrm{~mol})$ in acetic anhydride $(5 \mathrm{~mL})$ under argon atmosphere was added sodium acetate $(0.096 \mathrm{~g}, 0.00117 \mathrm{~mol})$ and the reaction mixture was refluxed for 16 hours. The reaction mixture was cooled and the solvent was removed under reduced pressure. This crude residue was dissolved in EtOAc $(25 \mathrm{~mL})$ washed with brine, $(2 \times 5 \mathrm{~mL})$ and water $(2 \times 5 \mathrm{~mL})$. The organic layer was dried over anhydrous sodium sulphate, concentrated and the residue was subjected to flash column chromatography on silica gel using hexane : ethyl acetate (90:10) as an eluent to give 16 as a white solid. Yield: 0.087 g, 61\%, m.p. $119-121{ }^{\circ} \mathrm{C}$ (Lit. $\left.{ }^{16} 120-122{ }^{\circ} \mathrm{C}\right)$; IR (KBr): 1755, 1732, 1697, 1607, 1427, $1224 \mathrm{~cm}^{-1} ;{ }^{1} \mathrm{H}$ NMR (400 MHz, acetone-d 6 ) $\delta: 2.40$ (s, 3H), 2.78 (s, 3H), 3.89 (d, 2H, J 5.6 Hz), $3.93(\mathrm{~s}, 3 \mathrm{H}), 4.94-5.05(\mathrm{~m}, 2 \mathrm{H}), 5.89-5.99(\mathrm{~m}, 1 \mathrm{H}), 7.43-7.46(\mathrm{t}$, $1 \mathrm{H}, J$ 7.2 Hz), 7.54-7.58 (td, 1H, J $1.2 \mathrm{~Hz}, J 7.9 \mathrm{~Hz}), 8.02(\mathrm{~d}, 1 \mathrm{H}, J 8.4 \mathrm{~Hz}), 8.24$ (d, 1H, J 7.6 $\mathrm{Hz}), 8.57(\mathrm{~s}, 1 \mathrm{H}) ;{ }^{13} \mathrm{C}$ NMR (100 MHz, acetone-d6) $\delta: 20.63\left(\mathrm{CH}_{3}\right), 26.98\left(\mathrm{CH}_{3}\right), 32.35\left(\mathrm{CH}_{2}\right)$, $52.57\left(\mathrm{CH}_{3}\right), 115.14(\mathrm{CH}), 115.66\left(\mathrm{CH}_{2}\right), 120.87(\mathrm{CH}), 121.30(\mathrm{CH}), 124.48(\mathrm{CH}), 125.61(\mathrm{Cq})$, $127.39(\mathrm{Cq}), 127.88(\mathrm{Cq}), 128.96(\mathrm{CH}), 133.73(\mathrm{Cq}), 134.18(\mathrm{Cq}), 137.44(\mathrm{CH}), 137.96(\mathrm{Cq})$, $140.54(\mathrm{Cq}), 168.05(\mathrm{Cq}), 168.26(\mathrm{Cq}), 171.38(\mathrm{Cq})$; HRMS: $\mathrm{m} / z . \mathrm{M}+\mathrm{Na}]^{+}$calculated for $\mathrm{C}_{21} \mathrm{H}_{19} \mathrm{NO}_{5} \mathrm{Na}: 388.1161$, found: 388.1161 .

\section{Acknowledgements}

We are thankful to IISc, Bangalore for providing HRMS facility. Durga P. Kamat is greatful to UGC, New Delhi for the award of NET-Senior Research Fellowship.

\section{References}

1. Knölker, H.-J.; Reddy, K. R. Chem. Rev. 2002, 102, 4303. https://doi.org/10.1021/cr020059j

2. Schmidt, A. W.; Reddy, K. R.; Knölker, H.-J. Chem. Rev. 2012, 112, 3193. https://doi.org/10.1021/cr200447s

3. Ito, C.; Katsuno, S.; Ohta, H.; Omura, M.; Kajiura, I.; Furukawa, H. Chem. Pharm. Bull. 1997, $45,48$. https://doi.org/10.1248/cpb.45.48

4. Wu, T.-S.; Huang, S.-C.; Wu, P.-L.; Teng, C.-M. Phytochemistry 1996, 43, 133. https://doi.org/10.1016/0031-9422(96)00212-9

5. Du, Y.-Q.; Liu, H.; Li, C.-J.; Ma, J.; Zhang, D.; Li, L.; Sun, H.; Bao, X.-Q.; Zhang, D.-M. Fitoterapia 2015, 103, 122. 
https://doi.org/10.1016/i.fitote.2015.03.018

6. Shen, D.-Y.; Chao, C.-H.; Chan, H.-H.; Huang, G.-J.; Hwang, T.-L.; Lai, C.-Y.; Lee, K.-H.; Thang, T. D.; Wu, T.-S. Phytochemistry 2012, 82, 110. https://doi.org/10.1016/j.phytochem.2012.06.019

7. Maneerat, W.; Ritthiwigrom, T.; Cheenpracha, S.; Laphookhieo, S. Phytochem. Lett. 2012, 5, 26.

https://doi.org/10.1016/j.phytol.2011.08.013

8. Maneerat, W.; Laphookhieo, S. Heterocycles 2010, 81, 1261. https://doi.org/10.3987/COM-10-11924

9. Kumar, V.; Vallipuram, K.; Adebajo, A. C.; Reisch, J. Phytochemistry 1995, 40, 1563. https://doi.org/10.1016/0031-9422(95)00452-D

10. Shyong, L. W.-; McChesney, J. D.; El-Feraly, F. S. Phytochemistry 1991, 30, 343.

11. Joshi, B. S.; Gawad, D. H. Indian J. Chem. 1974, 12, 437.

12. Bhattacharyya, P.; Chowdhury, B. K. Chem. Ind. 1984, 301.

13. Shen, D.-Y.; Chan, Y.-Y.; Hwang, T.-L.; Juang, S.-H.; Huang, S.-C.; Kuo, P.-C.; Thang, T.

D.; Lee, E.-J.; Damu, A. G. Wu, T.-S. J. Nat. Prod. 2014, 77, 1215. https://doi.org/10.1021/np500088u

14. Kamat, D. P.; Parsekar, S. B.; Kamat V. P.; Tilve, S. G. Synthesis 2014, 46, 2789. https://doi.org/10.1055/s-0034-1378521

15. Kamat, D. P.; Kamat, V. P.; Tilve, S. G. New Frontiers in Chemistry - from Fundamentals to Applications, BITS Pilani, Goa, India, December 18-19, 2015: Abstract No. 92.

16. Markad, S. B.; Argade, N. P. Org. Lett. 2014, 16, 5470. https://doi.org/10.1021/o1502721r

17. Martin, T.; Moody, C. J. J. Chem. Soc. Perkin Trans. 1 1988, 235. https://doi.org/10.1039/p19880000235

18. Humne, V. T.; Naykode, M. S.; Ghom, M. H.; Lokhande, P. D. Tetrahedron Lett. 2016, 57, 688. https://doi.org/10.1016/j.tetlet.2016.01.002

19. Abbas, Y.; Mansha, M.; Ullah, N. RSC Advances 2016, 6, 26104. https://doi.org/10.1039/C6RA03242G

20. Liu, Y.; Guo, Y.; Ji, F.; Gao, D.; Song, C.; Chang, J. J. Org. Chem. 2016, 81, 4310. https://doi.org/10.1021/acs.joc.6b00729

21. Brenna, E.; Fuganti, C.; Serra, S. Tetrahedron 1998, 54, 1585. https://doi.org/10.1016/S0040-4020(97)10366-0

22. Markad, S. B.; Argade, N. P. J. Org. Chem. 2016, 81, 5222. https://doi.org/10.1021/acs.joc.6b00702

23. Eaton, P. E.; Carlson, G. R.; Lee, J. T. J. Org. Chem., 1973, 38, 4071. https://doi.org/10.1021/jo00987a028

24. Jana, A.; Pahari, P.; Mal, D. Synlett 2012, 23, 1769. https://doi.org/10.1055/s-0031-1290380 
25. Lebold, T. P.; Kerr, M. A. Org. Lett. 2008, 10, 997. https://doi.org/10.1021/ol703085f

26. Xu, M.; Fan, T.-Y.; Zhang, J.-X.; Hao, X.-J.; Liu, S. Chinese Chem. Lett., 2015, $26,282$. https://doi.org/10.1016/j.cclet.2014.11.026 